\title{
Origin of the Griquatown granular iron formation, South Africa, in the context of the Great Oxidation event.
}

\author{
MEHRNAZ SIAHI ${ }^{1}$ AND HARILAOS TSIKOS ${ }^{2}$
}

\author{
${ }^{1}$ University of Ferdowsi Mashhad \\ ${ }^{2}$ Rhodes University \\ Presenting Author: mehrnazsiahi56@gmail.com
}

The mineralogy of iron formations (IF) has variously been interpreted as being predominantly diagenetic in origin through processes of organic matter re-mineralization and coupled Fe-Mn reduction, thus placing limitations on the utility of common IF minerals (such as magnetite and siderite) as proxies of primary water-column processes in deep time. In this study, we present results from the Griquatown granular IF (GIF) of the Transvaal Supergroup, South Africa, which appears to have been deposited at the dawn of the Great Oxidation Event (GOE) at $2.4 \mathrm{Ga}$. The Griquatown GIF contains high concentrations of manganese, hosted exclusively in the carbonate fraction of the rocks [1]. Here, we place emphasis on the carbonate fraction of a variety of granular sub-facies, using basic petrography combined with micro-analytical applications.

Griquatown granules show much variability in both size and shape. Their composition is dominated by iron carbonate minerals (siderite, ankerite), which show common textural evidence of having derived from replacement of precursor high Mg-calcite [1]. Different types of granules observed in the Griquatown GIF can be tentatively subdivided into ooids, peloids and micro-granular aggregates, in broad analogy to modern calcareous counterparts. Micro-granular aggregates are reported for the first time, and display curious chemical zonation of carbonate-hosted chemical elements, especially manganese.

We contend that all granular components of the Griquatown GIF would have precipitated directly from a high-energy shallow marine environment supersaturated with respect to both carbonate and $\mathrm{Mn}(\mathrm{II})$. We infer a likely biogenic origin for at least the granular micro-aggregates, possibly in the form of welded, calcified micro-organisms that utilized dissolved Mn compounds for their metabolic processes. We further entertain the notion that the combination of calcite and Mn saturation in ambient seawater at the time of deposition, may have constituted the ideal chemical background for biological innovation and the development of photosystem II. The foregoing would have successively led, at post-Griquatown times, to the onset of the GOE; global glaciation via oxidation of reduced carbon in the atmosphere and increased $\mathrm{CO}_{2}$ drawdown (Huronian/Makganyene glaciation); and ultimately to the first event of massive sedimentary deposition of oxidised Mn compounds in association with the younger Hotazel IF. 